\title{
The Perspectives of Online English Language Teaching and Learning during the Pandemic
}

Shamimah binti Haja Mohideen

To Link this Article: http://dx.doi.org/10.6007/IJARBSS/v11-i10/11458

DOI:10.6007/IJARBSS/v11-i10/11458

Received: 24 August 2021, Revised: 26 September 2021, Accepted: 09 October 2021

Published Online: 25 October 2021

In-Text Citation: (Mohideen, 2021)

To Cite this Article: Mohideen, S. binti H. (2021). The Perspectives of Online English Language Teaching and Learning during the Pandemic. International Journal of Academic Research in Business and Social Sciences, 11(10), $903-921$.

\section{Copyright: () 2021 The Author(s)}

Published by Human Resource Management Academic Research Society (www.hrmars.com)

This article is published under the Creative Commons Attribution (CC BY 4.0) license. Anyone may reproduce, distribute, translate and create derivative works of this article (for both commercial and non-commercial purposes), subject to full attribution to the original publication and authors. The full terms of this license may be seen at: http://creativecommons.org/licences/by/4.0/legalcode

Vol. 11, No. 10, 2021, Pg. $903-921$

Full Terms \& Conditions of access and use can be found at http://hrmars.com/index.php/pages/detail/publication-ethics 


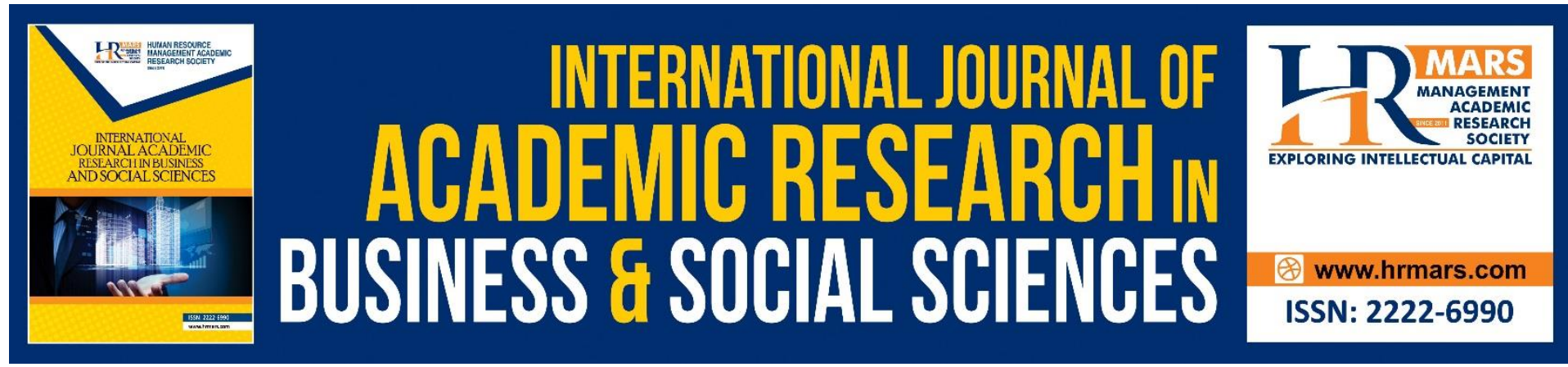

\title{
The Perspectives of Online English Language Teaching and Learning during the Pandemic
}

\author{
Shamimah binti Haja Mohideen \\ Jabatan Bahasa Inggeris, Pusat Bahasa dan Pengajian Asasi, Universiti Sultan Azlan Shah \\ Kuala Kangsar, Perak
}

\begin{abstract}
The Covid-19 pandemic has forced classrooms to shift from face-to -face to fully online learning. This requires a great adjustment for teachers and students. There have been comparisons between the two modes and discussions on which one being "better" and faceto-face is generally preferred by both teachers and learners. Before deciding to choose one over the other, we need to understand the advantages and disadvantages of both from the experience of teachers and learners. Therefore, a study was conducted on 71 students taking English courses and about 20 English teachers from Sultan Azlan Shah University. The study found that online classes are more advantageous in convenience, flexibility, availability of teaching and learning resources, economy of time and cost. The responses given by most of the students also show that the switch to online mode has not affected their learning. They were able to absorb their lessons and acquire the skills taught just as well. However, responses from teachers, be they from surveys or qualitative inquiries, found that online classes have limitations in interaction, collaboration, communication and learner discipline among others. Therefore it is necessary to find ways to make learner discipline, interaction, collaboration and communication effective to fully develop the potential of online learning success. It can be concluded that blended learning would be the most ideal since it is a loss to choose one mode over the other. Blended learning has already been implemented in several universities in Malaysia and the rest of the universities can consider following suit.
\end{abstract}

Keywords: Online Learning, Face-To-Face Learning, Blended Learning

\section{Introduction/background}

The Covid 19 lockdown began in Malaysia on $18^{\text {th }}$ March and had caused education to change dramatically, with the distinctive rise of e-learning. This required great adjustment on the parts of the teachers and students. Due to the sudden emergence of the pandemic, in a short time, all teaching had to be shifted online. A complete online course needs an elaborate lesson plan, design and development of teaching materials such as audio and video contents which take time to prepare, and not forgetting the need of technology support teams. Most teachers lack online teaching experience, prior preparation, or support from educational technology teams (Bao, 2020). As a result, teachers need to self-train and explore a wide range of virtual learning tools and software, including virtual tutoring platforms and learning management systems. 
Despite a wide range of online teaching tools to conduct live-lessons, an online lesson may not go well for students from disadvantaged backgrounds. They have to struggle to keep up with their virtual classes and classmates. Some do not have regular access to laptops or tablets, while some others have limited (or non-existent) WiFi connections. The introduction of online lessons has sparked an online vs face to face classroom debate. It appears that online classrooms are here to stay for quite some time until the Covid-19 pandemic ends. Should the pandemic end, will online classroom end with it?Or are some of the changes here to stay? This study will look at the distinction between offline and online language learning and discuss different ways of knowledge generation which are appropriate for the different learning environments.

\section{Objective}

This study presents an exploratory investigation designed to identify the following:

1) Students' views on the advantages and disadvantages of online English language learning.

2) English teachers' views on the advantages and disadvantages of online English language teaching.

3)To categorize areas in which online English language teaching and learning are advantageous and otherwise.

\section{Research Questions}

1. How do students evaluate their online learning experience?

2. How do teachers evaluate their online teaching experience?

3. In which aspects can English language teaching and learning be maintained online?

\section{Literature Review}

Rather than debating which mode of learning is better (or worse), which Blake (2009:823) calls the 'wrong research question,' we need to find ways to make online learning courses more effective. Due to a combination of factors (for example cost, convenience, learner expectations, developments in technology, and changing paradigms within education), it is clear that online learning is here to stay. Whether

an online course is 'better' (or 'worse') than a face-to-face equivalent rests on a multitude of factors, other than the delivery mode (Hockly, 2015).

In comparing face-to-face and online classes, Montiel-Chamorro (2018) found contradictory results on the performance of students. Some studies have indicated that given the same conditions, students in online settings perform better than their face-to-face counterparts while other studies demonstrate that either there are no significant differences in the outcomes of face-to-face students compared to online students ( $\mathrm{Ni}, 2013$ ), or that face-toface students outperform online students (Heppen et al., 2017).

Bourelle et al. (2016) analyzed the assessment scores from three sections of English 102 (two online and one face-to-face) at the University of New Mexico to compare student learning of multimodal literacies in online and face-to-face courses. The results of the online students were found to be better than the face-to-face students. According to them, the cause of these results could be due to the 12 quick formative feedback students in the online settings received, which was more difficult to do for the face-to-face classes due to time restrictions. 
Some other studies have found that there is no difference in the outcomes for students who took their courses online and those who took them face-to-face. Ni (2013) conducted a 2year study to compare student performance in online and face-to-face classes in terms of interaction and efficacy in a public administration class. To compare learning effectiveness, a total of 6 classes were used. Three classes received online instruction while the other three attended face-to-face classes. The program used was the same for all online and face-to-face classes and they were taught by the same instructor. The results obtained through student performance records and surveys showed that student performance is independent of the mode of instruction. The conclusion from these studies support the idea that students' characteristics play an important role in the success or failure of online courses.

There are certain characteristics often found in successful online students. These students usually have an internal locus of control, self-motivation, and independence. They establish how much interaction they need with the instructor and seek clarification in advance of deadlines (Montiel-Chamorro, 2018). In addition, Mehrotra and McGahey (2012) suggest that students need to monitor their own progress in acquiring skills and knowledge. Successful online students demonstrate self-regulation and show a positive attitude.

\section{Frameworks for Online Learning}

Community of inquiry. The Col framework is an approach that supports the processes of teaching and learning in online settings. This framework was presented by Garrison, Anderson and Archer (2000) and is seen as a coherent and credible theory (Akyol \& Garrison, 2013). One characteristic of a successful online course is its capability to create a Col where learners, instructors, and learning materials interact to develop knowledge and skills (Rubin, Fernandes, and Avgerinou ,2013).

Social presence. Using Vygotsky's (1978) view of learning as a social activity, interaction between instructors and students becomes essential to the learning process. Current technology facilitates this interaction, reinforcing social presence of teachers and learners within the online environment.

Cognitive presence. Students begin with the stage of inquiry and exploration, then moves to application with subsequent tasks, activities and intervention. This generally depends on the teaching presence (Rienties et al., 2012).

Teaching presence. Senior (2010) points out that teaching presence has been divided into three components: (a) instructional design and organization, (b) facilitating discourse, and (c) direct instruction. The way instructors design and set up their courses influence how students perceive them in the online classroom. Communication tools such as the discussion forums and online meeting platforms help facilitate the discourse and promote student-student and student-teacher interaction. According to Akyol and Garrison (2013), there can be a meaningful learning experience only when all the three elements are balanced and have been developed in a collaborative environment. The Col framework emphasizes that humans build knowledge together and need each other to progress at any level and area. Therefore, this framework is widely linked to the concepts of constructivism and social constructivism 
Constructivism and Social Constructivism Piaget (1952) stated that humans construct knowledge based on their own experiences and actions. According to Akyol and Garrison (2013), the essence of constructivism is that "the individual is responsible for making sense (creating meaning) of new experiences by building on and integrating previous knowledge and experiences" (p. 3).It has been recommended that online courses have a studentcentered, constructivist approach to learning (Palloff \& Pratt, 2011). More specifically, online courses need social interaction to solve problems and build knowledge. Social constructivism is a branch of constructivism found in the work of Vygotsky (1978), where learning is socially supported and it requires collaborative inquiry. Additionally, Senior (2010) reports that scholars in the field of e-learning recognize the relationship between technology based interactions and the social constructivism theory. Senior (2010) also suggests that students will collaboratively build new understandings when they are actively engaged in educational experiences with guidance from their teachers or more experienced peers, and when they are encouraged to share ideas in an environment where all participants have a voice. She adds that teachers collaborate with students to create knowledge and understanding.

\section{Methodology}

A sociocultural framework, which goes beyond quantitative research approaches, is necessary to adequately understand the experiences of language learners and teachers who share a common interest in the new digital learning environments. Therefore, qualitative methodologies are used to confirm and add details to the findings from quantitative methods.

A survey was conducted on ESL students from the researcher's English classes and teachers from the English Language Department at Universiti Sultan Azlan Shah, in Kuala Kangsar, with separate survey questions for both groups to gauge their online teaching and learning experience. Most of the questions are Likert Scale questions that evaluate the degree of effectiveness of online learning and teaching on various matters such as flexibility, efficiency in time and resources management, catering to various learners, transmission of knowledge and skills, teaching and learning resources, communication and learning management and discipline among others. Respondents are to rate from number 1 to 5 , number 1 being very poor and number 5 being very good. Some questions require respondents to give their opinions by rating their level of agreement from number 1 to 5 , number 1 being strongly disagree and number 5 being strongly agree. 71 students and 20 teachers participated in the survey. The participants were selected with convenience sampling. 6 English classes of the researcher were used. 3 of them were initially from face to face class but the increasing cases of Covid 19 in the local area forced the university to switch all classes online. The data from the survey were analysed quantitatively.

The qualitative methods used involved questioning the students, paying attention to the teachers' views and observation of the researcher's own English classes. The results are based on an analysis of responses by students/staff and field notes from observation.

In this exploratory study, learners were allowed to express themselves freely about digital learning in a few online discussion activities administered by the researcher in order to help distance educators support them appropriately. Among the aspects that were investigated included beliefs, learning process and motivation. Their comments in the online discussion provide rich insights into the advantages and disadvantages, pleasures and frustrations, 
comforts and anxieties of learning a language at a distance, and the strategies learners use to manage their learning in a distance environment.

In observation of English classes, comparisons are also made with the traditional classroom, which all have been accustomed to. With lockdowns on and off, students and teachers are experiencing two different modes of learning and teaching.

\section{Results and Discussion}

\section{General Responses of Teachers and Students}

In qualitative discussion on comparison between face-to-face and online mode, in general, both teachers and students favour the face-to-face mode. However, survey responses reveal that most of the students from the researcher's English classes are able to adapt to their online lessons while the teachers in the English department continue to adjust and try their best in their service. Among the reasons some teachers prefer face-to-face learning is that they do not have the expertise to conduct successful lessons in a high tech digital form. Some are still making themselves familiar with various applications. There are students without reliable internet access and/or technology who struggle to participate in digital learning. In Malaysia, $37 \%$ of students do not have internet access to follow online classes.

Results of both the students and teachers' survey found that most respondents gave good ratings of online lessons with regard to convenience, flexibility, saving time and cost. The respondents also gave positive response with regard to availability of resources.

\section{Flexibility in methods of conducting the lesson .}

\section{5 responses}

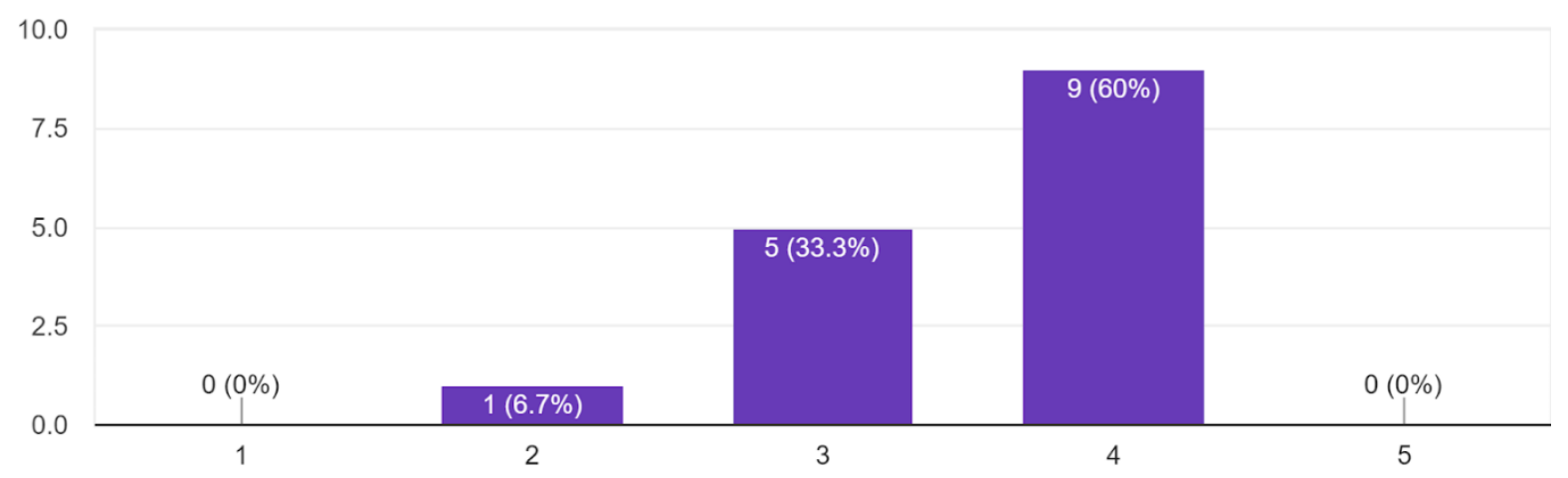

Graph 1 : Teachers responses regarding flexibility of online classes. 
2. Flexible for students with other commitments (e.g. job, family responsibilities.Fleksibel untuk pelajar yang mempunyai komitmen lain seperti kerja dan tanggungjawab keluarga.

71 responses

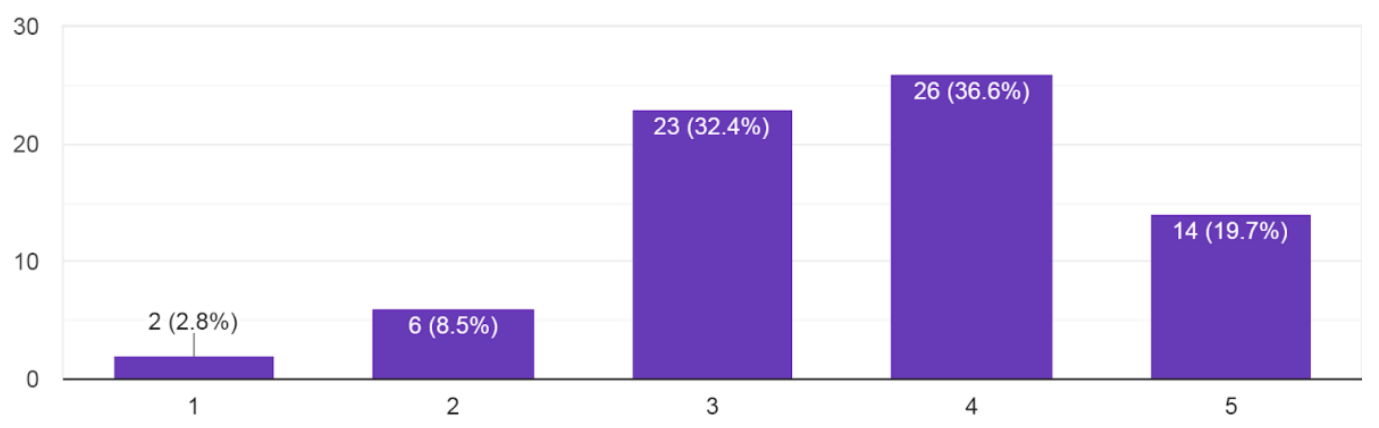

Graph 2: Students' responses regarding flexibility of online classes.

Flexibility has been cited one of the main advantages of online lessons for both teachers and students (please refer to Graphs 1 and 2.) Students and teachers are not required to go to a classroom and can teach or learn at the comfort of their own homes or stations. If students have missed lessons due to unavoidable circumstances or poor internet connection, they could access pre-recorded videos of teachers and materials uploaded on learning management system at any time and place.

With online lessons, it is easier for teachers to show audio visual materials to students by just sending them links and students can view them in their own laptops or phones. The teacher does not need to depend on classroom facilities and limited access to language labs and audio visual rooms.

Delivery of lesson content can at times be more efficient by using pre-recorded videos which can be accessed at any time and place, replayed as many times as needed, paused or stopped when the students need a long break and resumed when ready to continue. Lessons from pre-recorded videos can be kept permanent.

3.Saving time and resources.

15 responses

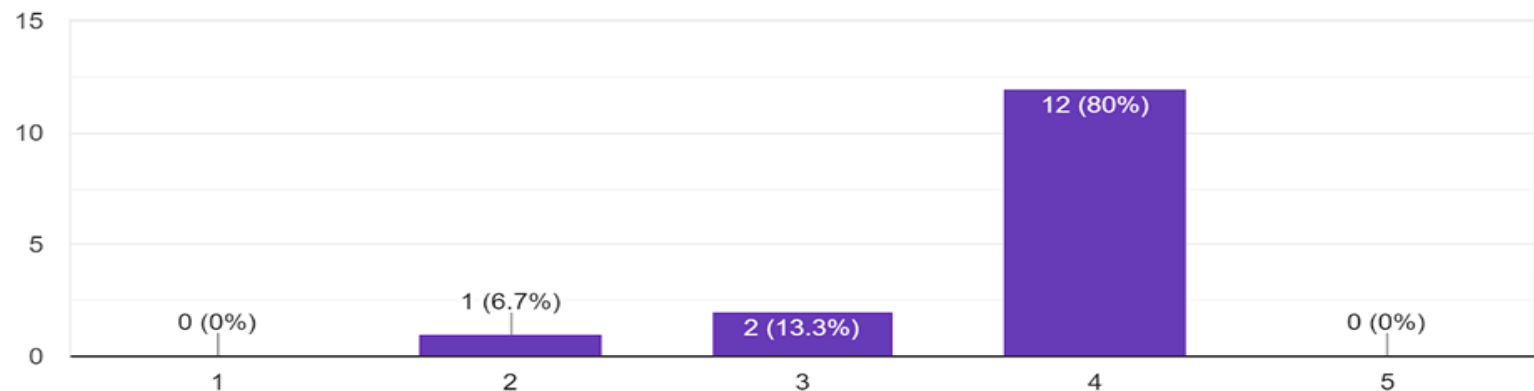

Graph 3 : Teachers' responses regarding the effectiveness of online classes in saving time and resources. 
3.Saving time and cost. Menjimatkan masa dan kos.

68 responses

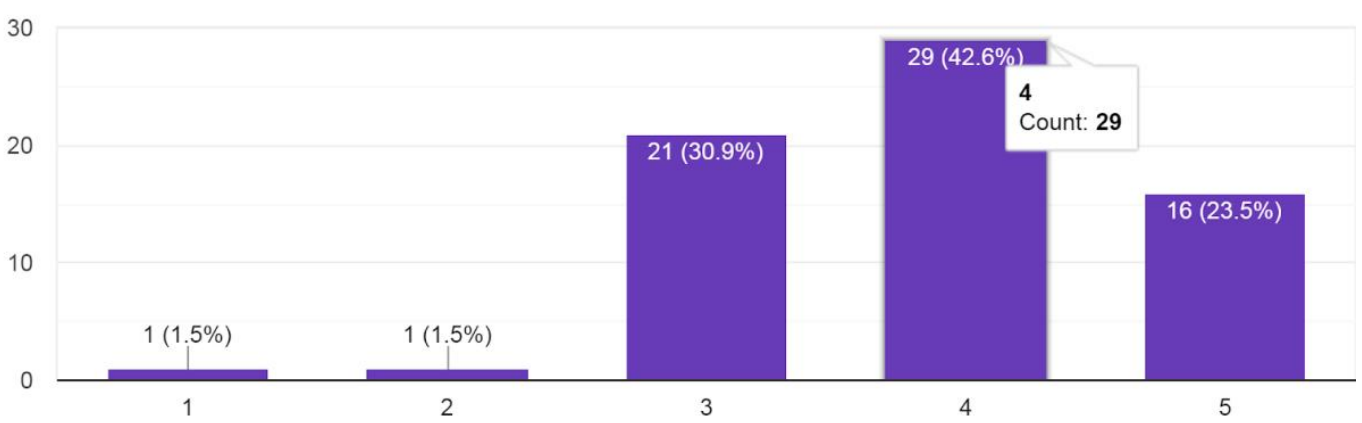

Graph 4 : Students' responses regarding the effectiveness of online classes in saving time and resources.

$80 \%$ of the teachers and $42.6 \%$ of the students gave a rating of 4 out of 5 in the effectiveness of online classes in saving time and cost while another $23.5 \%$ of the students rated 5 out of 5 (please refer to Graphs 3 and 4). By conducting and attending classes online, a lot of time which is otherwise used to prepare to get to the classroom is saved. There are teachers and students who have to travel to the campus to attend face-to-face classroom. The time saved can be used to prepare for the lessons. Most of the materials in online classes are paperless. This saves cost in printing, making Xerox copies or buying hardcopies of learning materials. For those who would otherwise need to travel, mileage and toll expenses are saved.

6.Availability of teaching and learning resources.

15 responses

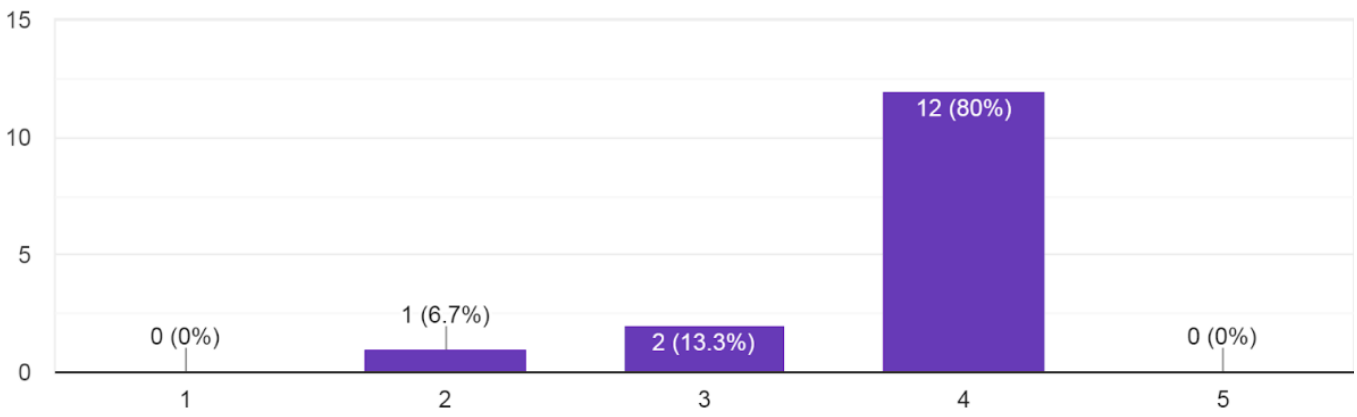

Graph 5 : Teachers' responses on the availability of teaching and learning resources. 
6.Availability of learning materials. Ketersediaan bahan pelajaran.

71 responses

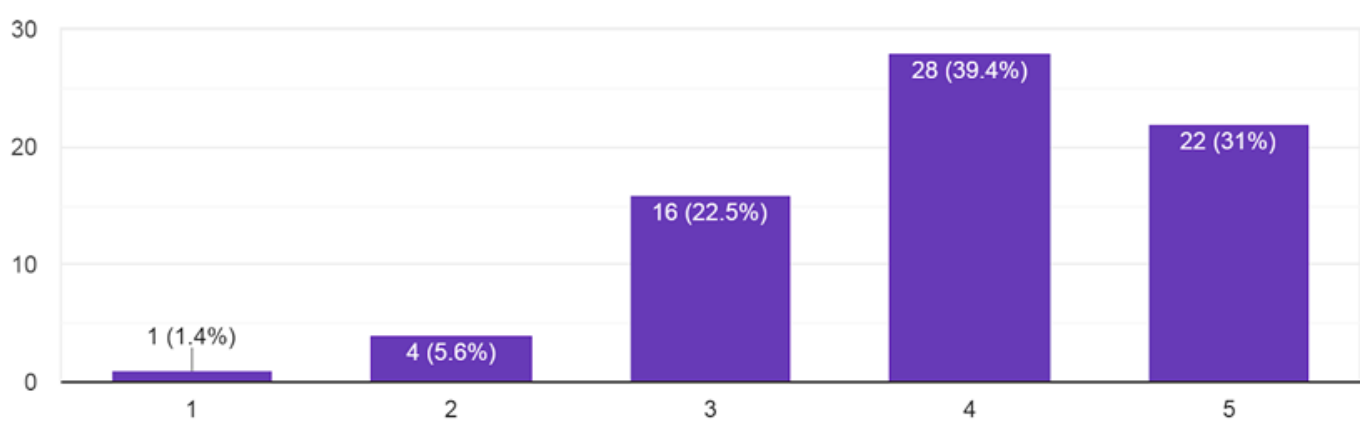

Graph 6 : Students' responses on the availability of learning resources.

Majority of the teachers and students rated at least 4 out 5 in the availability of teaching and learning resources (please refer to Graphs 5 and 6). It is undeniable that there is a wealth of online resources for learning English. These are easily accessible with just clicks of a mouse.

Regardless of the constraints faced in teaching and learning online, both groups of participants agree that the success of online teaching and learning relies and the teachers' and students' own initiative and strategies (please refer to Graphs 7 and 8).

1. Online teaching and learning can be successful if done in an effective way.
15 responses

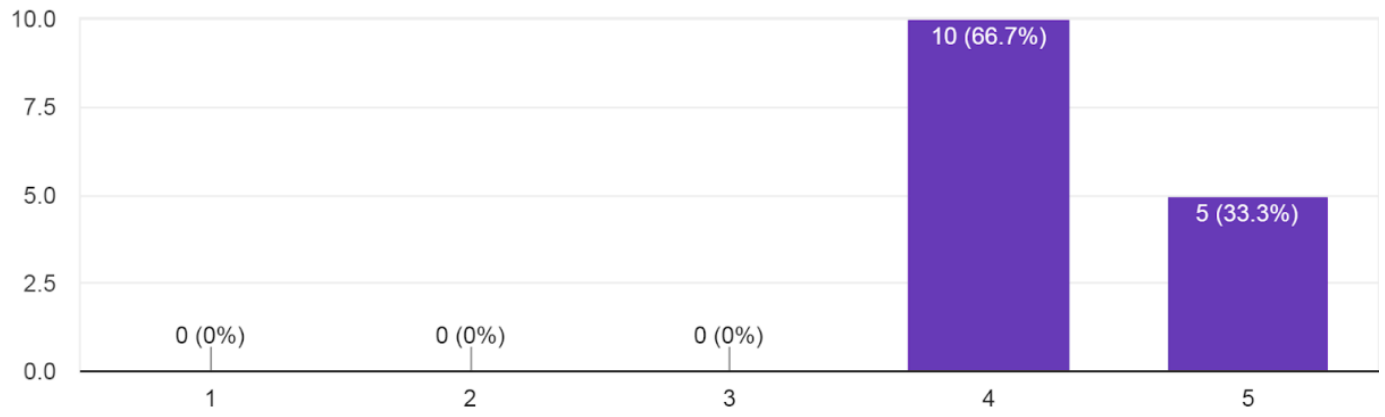

Graph 7 : Teachers' responses about the success of online teaching and learning. 
Students can learn as much as they do in face to face learning with the right attitude and learning strategies. Pelajar masih boleh belajar dengan bai...engan sikap and strategi pembelajaran yang betul.

71 responses

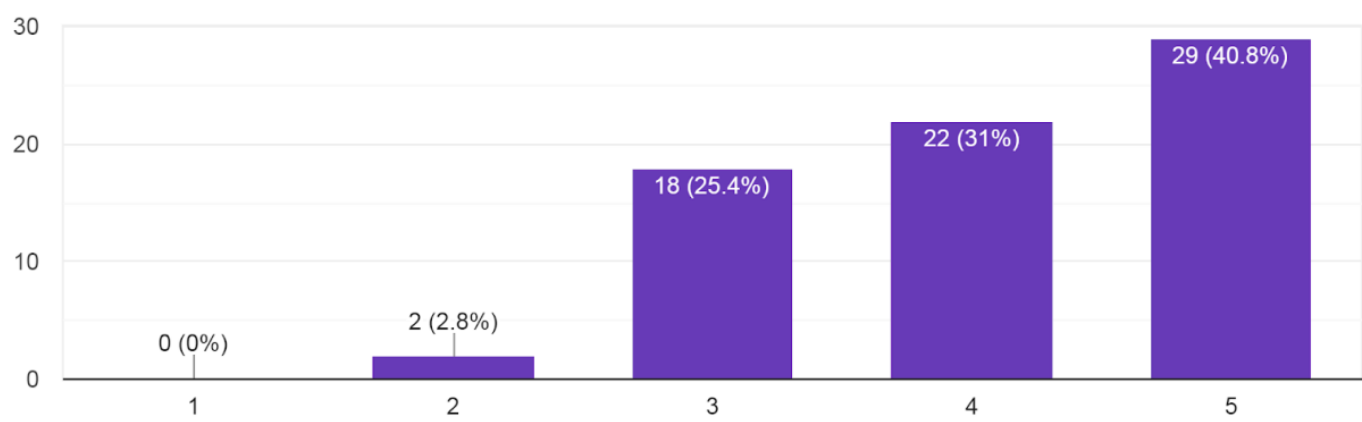

Graph 8 : Students' responses about the success of online learning.

Both groups also agree that it is best to implement blended learning for optimum results (please refer to Graphs 9 and 10)

2. It is best to implement blended learning (combination of online and face-to-face) lessons as one completes the other.

15 responses

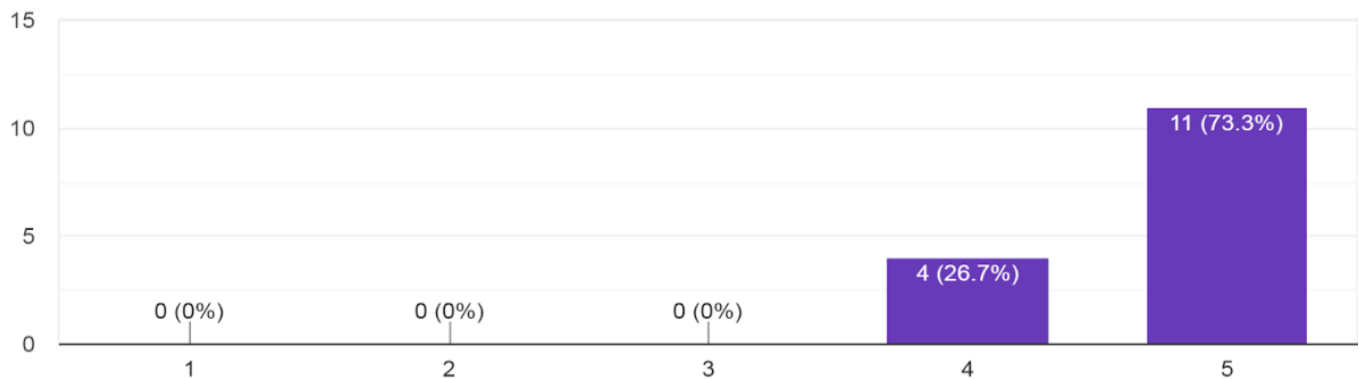

\section{Graph 9 : Teachers' responses towards blended learning}

3. It is best to implement blended learning (combination of online and face-to-face) lessons as one completes the other. Adalah terbaik untuk mengga...lajaran dalam talian dan pembelajaran bersemuka. 71 responses

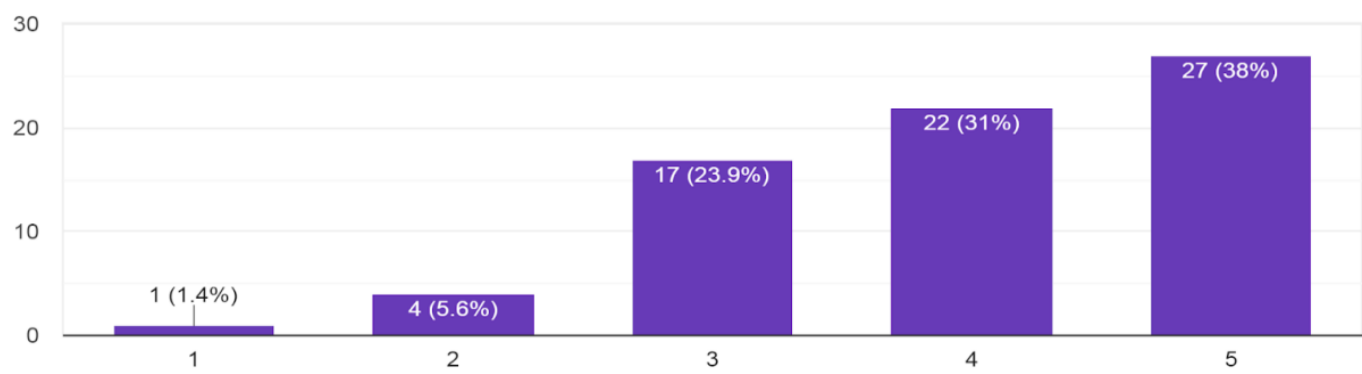

Graph 10 : Students' responses towards blended learning 


\section{Students' Responses}

Survey results from students show that their feedback on their online learning experience is in general, positive. Majority of the students gave good ratings on access to audio visual materials (please refer to Graph 11.) Most do not deny that they can still get knowledge and skills from online learning (please refer to Graph 12.) This shows that the switch to online mode during pandemic does not deter learning. It also trains them to learn independently (please refer to Graph 14). No doubt learning online enables students to be autonomous learners. They can develop at their own pace without having to pressure themselves to catch up with others or feel dragged down by those slower than them. Because online lessons have their advantages, with access to the right technology and used well, students retain 25$60 \%$ more material when learning online compared to only $8-10 \%$ in a classroom. This is mostly going back and re-reading, skipping, or accelerating where necessary due to being able to learn faster online. E-learning requires $40-60 \%$ less time to learn than in a traditional classroom because students can learn at their own pace, according to their needs and abilities (Li \& Lalani, 2020).

Although it is said that the online mode is not ideal when it comes to communication between teacher and students, the ratings of the students show that most of the students do not have problems communicating with their teachers (please refer to Graph 13.) This is perhaps due to the many online communication applications available such as Whatsapp, Google Meet, Zoom, etc with which the teachers have made themselves available for students to consult them.

\footnotetext{
7.Access to audiovisual materials. Mudah mengakses bahan audiovisual.

71 responses
}

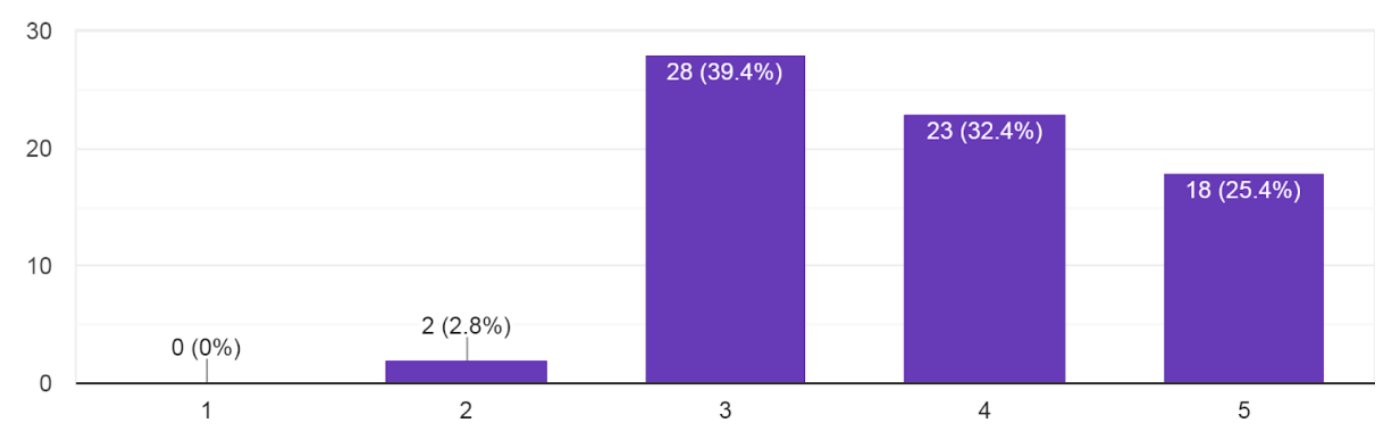

Graph 11 : Students' ratings on access to audio visual materials 
5. Getting knowledge and skills. Mendapat ilmu dan kemahiran.

71 responses

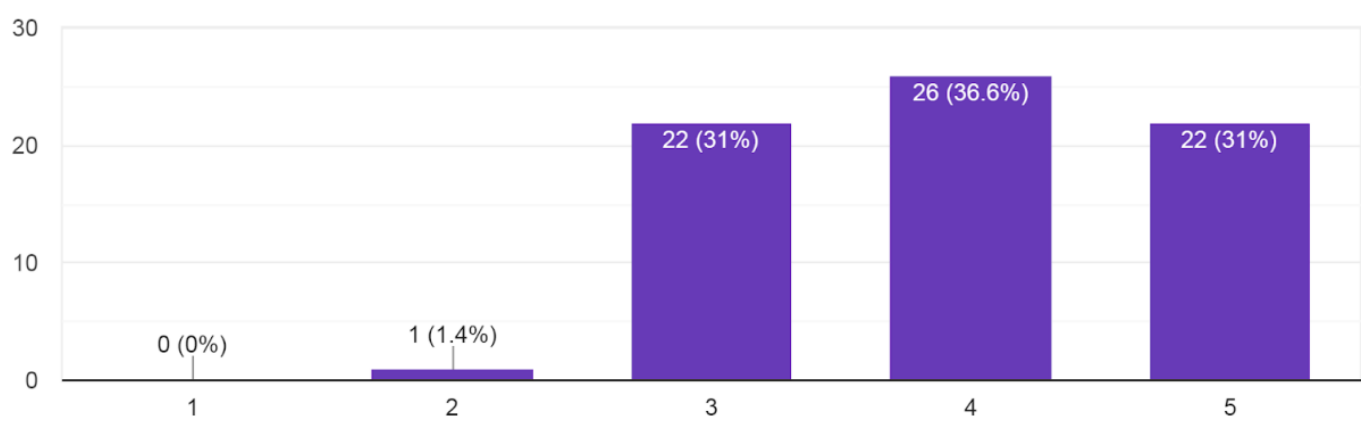

Graph 12 : Students' ratings on the effectiveness of online lessons in gaining knowledge and skills

8. Communication with teacher and other students. Komunikasi antara guru dan pelajar,

70 responses

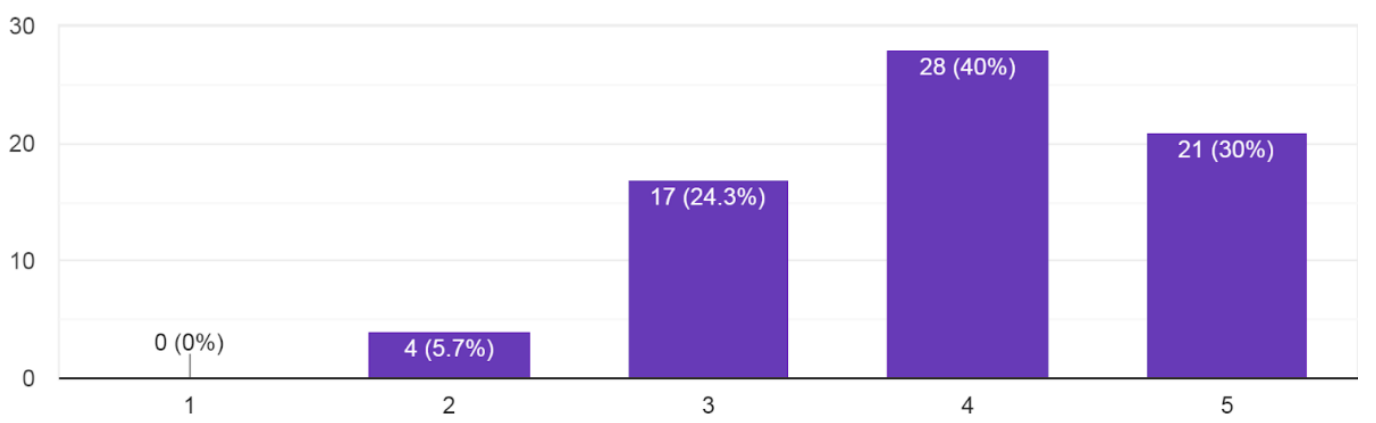

Graph 13 : Students' ratings on communication between teacher and students.

10. Training students to learn independently. Melatih pelajar untuk berdikari dalam pembelajaran.

71 responses

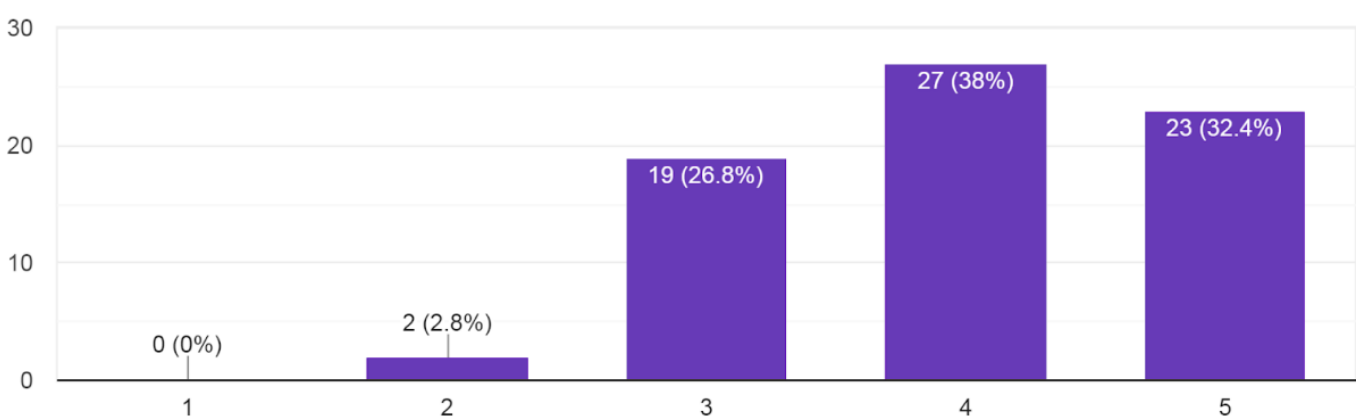

Graph 14 : Students ratings on independent learning. 


\section{Responses of Teachers}

Responses of teachers show that the online mode does not affect the pace of their teaching (please refer to Graph 15). This is perhaps because most of the teachers and students in Universiti Sultan Azlan Shah do not have poor internet connection.

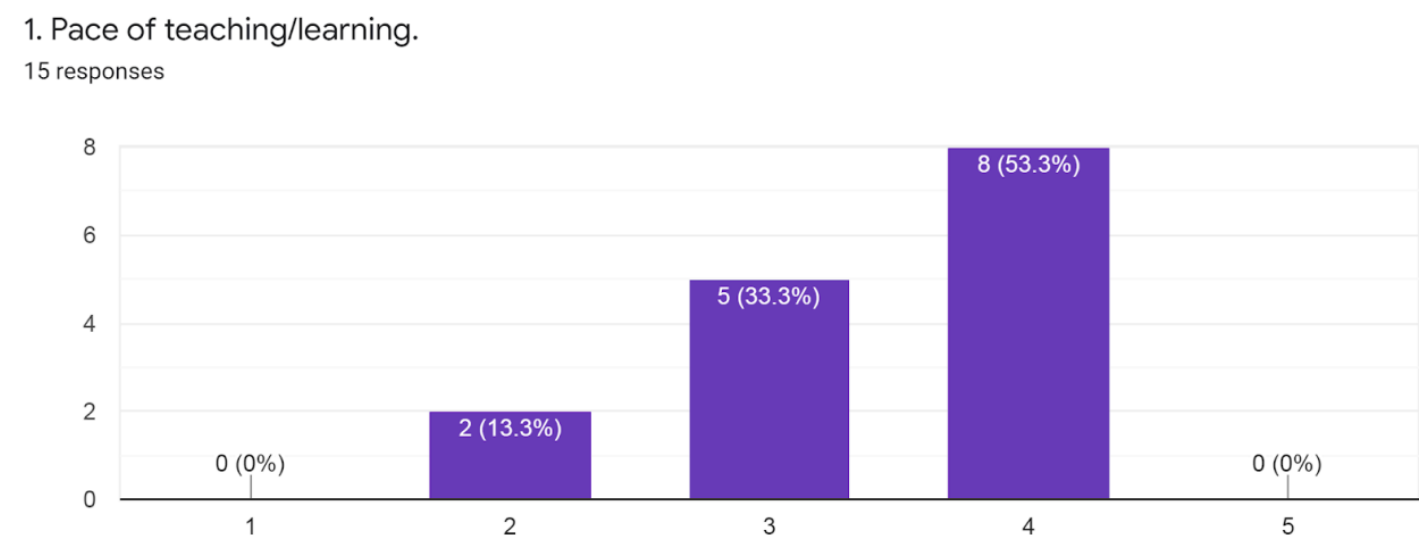

Graph 15: Teachers' ratings on pace of teaching and learning

However, much leaves to be desired in terms of catering to different learners, efficiency of content delivery, collaborative and interactive learning, communication and learner discipline. All these factors which are found in face-to-face classes are perceived to be lacking.
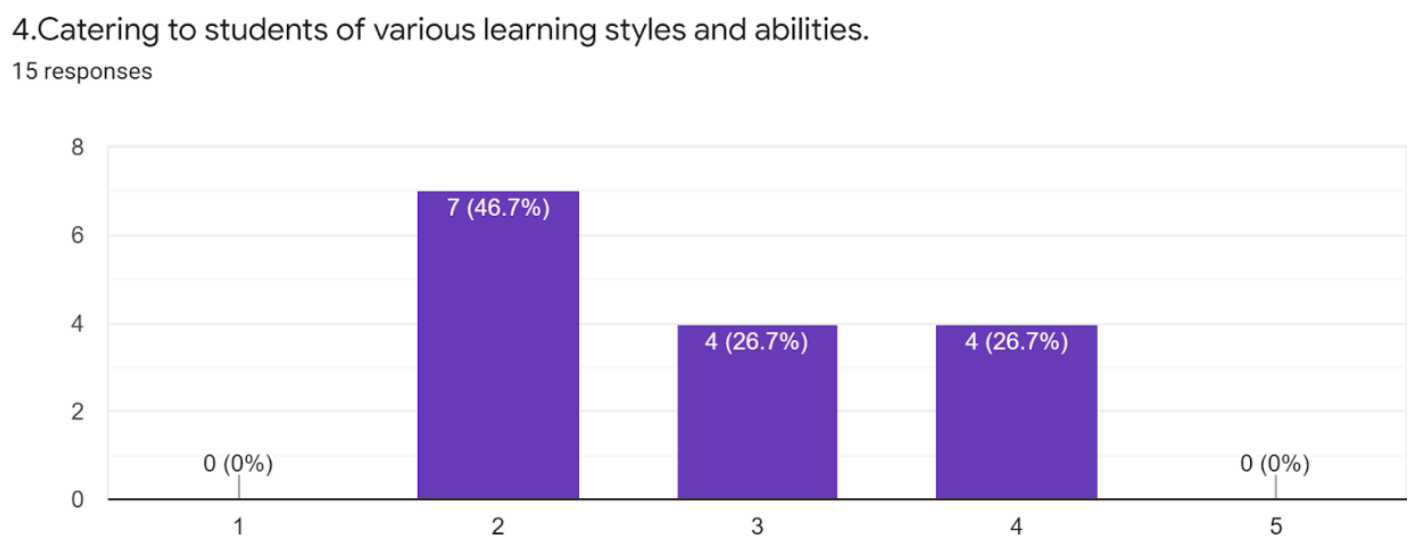

Graph 16: Teachers' ratings on the effectiveness of online lessons to cater to various learners.

The researcher's own observation of her classes confirms the responses of the teachers regarding the effectiveness of online classes in catering to all kinds of learners (please refer to Graph 16) Weak students need additional guidance from teachers which can only be provided face-to-face. They struggle to follow online classes, which require them to be able to learn independently. The CGPA of most of the researcher's students are above 3.0. There is a link between their CGPA and positive responses towards online lessons. Online learning works for students who are bright, disciplined and able to learn independently. 
8. Communication between teacher and students.

15 responses

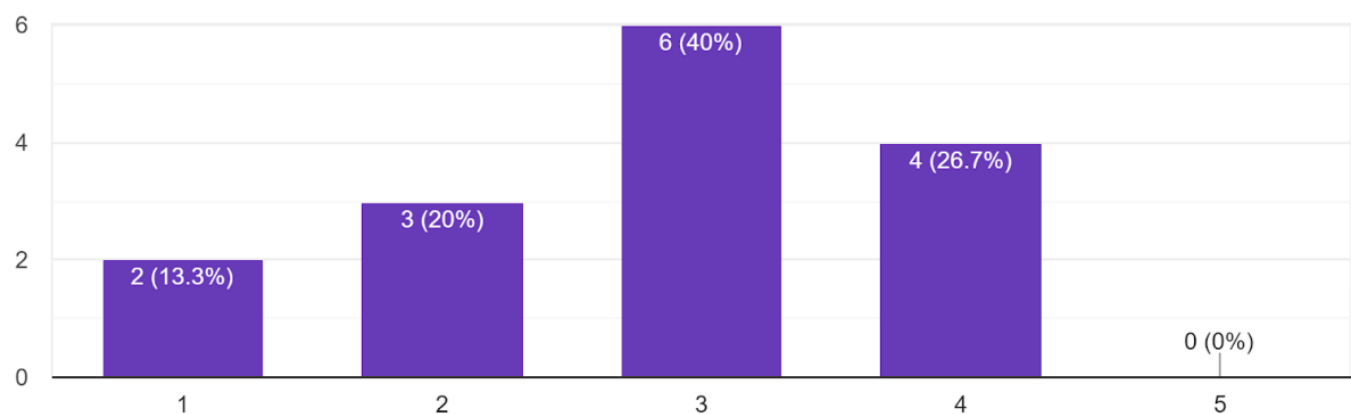

Graph 17: Teachers' ratings on the effectiveness of online lessons in communication between teacher and students.

Although students gave positive responses regarding communication in their survey, the results seem to be the opposite for teachers (please refer to Graph 17). Teachers report having difficulty communicating with their students. Lack of face to face and direct communication creates a communication barrier. Online lessons pose some challenges in getting and giving feedback.

\section{Learner discipline.}

15 responses

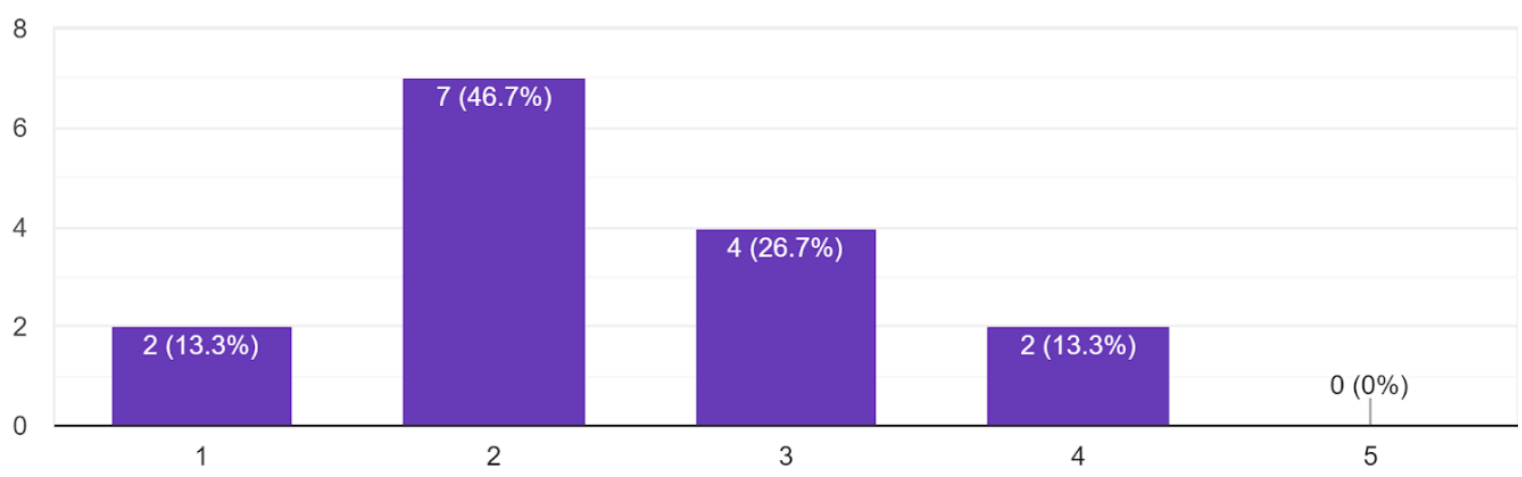

Graph 18: Teachers' ratings on learner discipline

Graph 18 shows the teachers' low rating on learner discipline. One particular aspect of the disadvantages is classroom and quality control. Since the students are behind the screen, there is no way of knowing whether they are participating in the lessons as is possible in a face-to-face classroom. Assessments conducted online are less reliable because cheating cannot be prevented behind the screen. As a result, the types of assessments given are limited to open book and take home tests which make students prone to plagiarizing their answers. 
Most of the respondents are not sure of the effectiveness of online lessons in conducting interactive and collaborative learning activities (please refer to Graphs 19 and 20). Collaborative and interactive learning activities are easier to conduct in a face-to-face classroom. This does not mean they are not possible to be done online. It just might not be the same as in a face-to-face class. Perhaps the teachers have yet to explore ways to make online classes more interactive and get students to collaborate in their learning activities. The literature review section has highlighted that teachers and students need to form a supportive virtual learning community that includes a lot of interaction and collaboration between the teacher and students and among the students. Regardless of the mode of learning, successful language learning needs a lot of interaction and learner-centred language activities. Incorporating these in online learning is possible with modern online communication technology provided that both teachers and students have good online facilities.

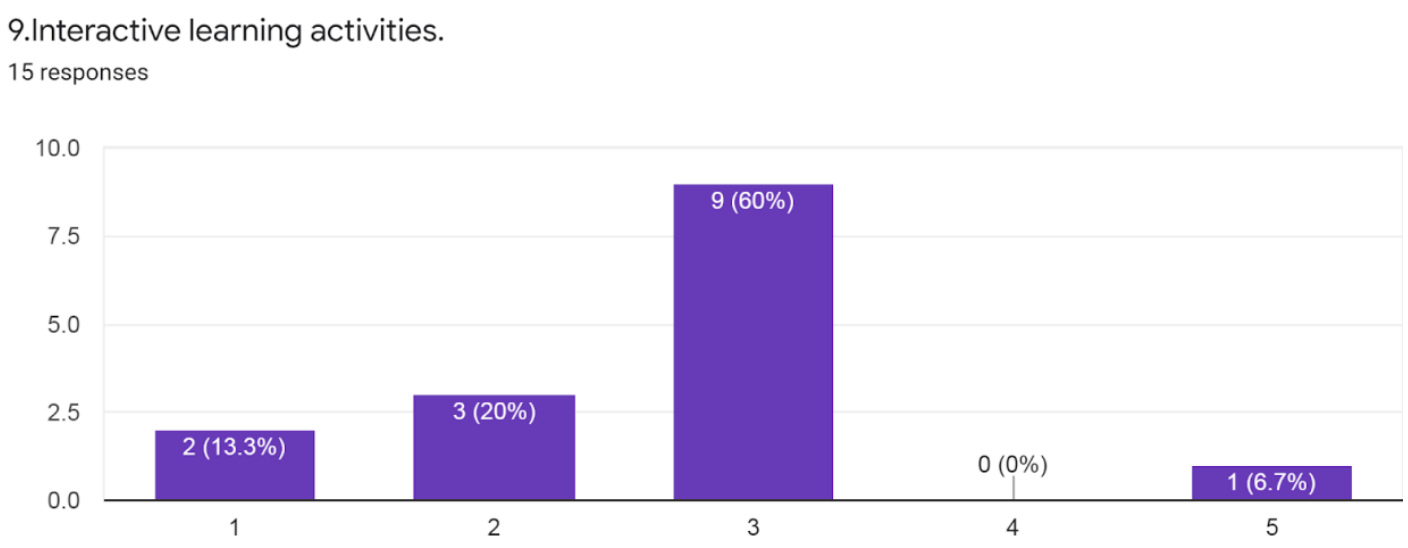

Graph 19 : Teachers' ratings on interactive learner activities

10.Collaborative learning

15 responses

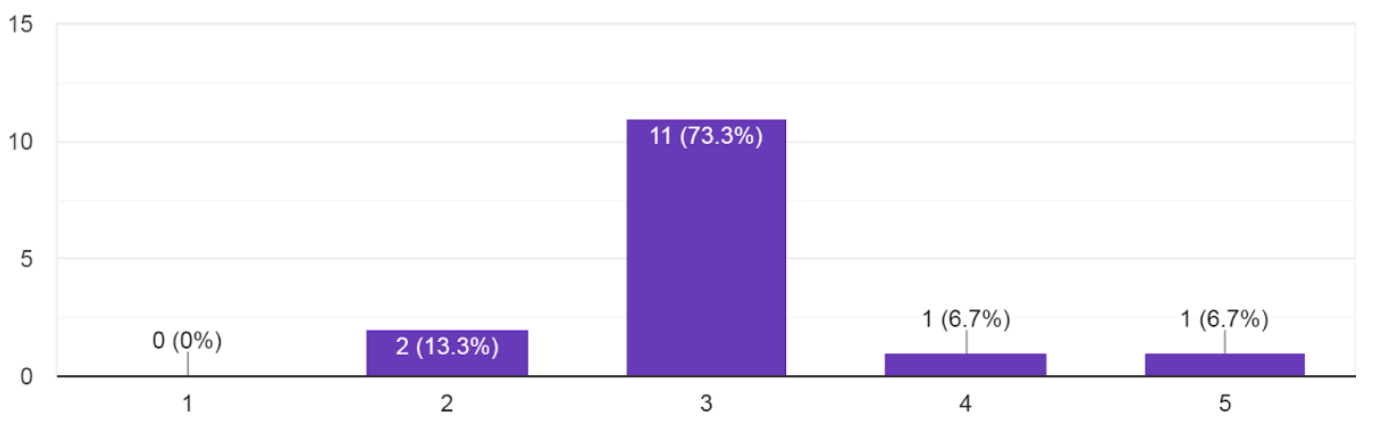

Graph 20 : Teachers' ratings on collaborative learning

Having seen the advantages and disadvantages, it can be inferred that online classroom can complement face-to-face classroom but never replace it. If given choice between the two, 
almost all respondents prefer the traditional classroom. The face-to-face classroom setting is necessary for learning. The purpose of attending classes is not to just learn the subject content. If that was the case, learning online independently is sufficient. The fully online mode can be an option only for special cases when classroom learning is not possible: - for working students who are unable to fit the class schedules into their routine and need the flexibility and during the pandemic when online learning is better than no learning at all. By attending classes, students interact with their peers. This helps them build people skills such as communication skills, training in teamwork which they will need in the real world. It has been mentioned earlier that one disadvantage of online classroom is that it only works for certain types of learners but in a face to face classroom, teaching style can be modified according to different learners' needs and learning styles. Through online, teachers are confined by the limitations of what activities they can conduct.

Although there is no denying that face-to-face is more effective than online teaching and learning, conducting a fully face-to-face course is likely to become outdated in the future. A fully face-to-face classroom is not without its limitations. Classroom lessons are dependent on what facilities are available and in good condition. Good facilities in some learning institutions are limited.

Traditional classroom consumes time in preparing for the class and resources. Online lessons require little preparation as both teacher and students just log on the screen. The time and money spent on travelling to the classroom is better used to prepare for the lessons. As for classroom management issues, in online lessons, it is easier to control disruptive students so that they are not able to distract the lesson for the whole class. Online applications enable the host to switch off mikes or even remove certain participants from the meeting room. In a traditional classroom some teachers are burdened with having to manage disruptive students as they teach. In a traditional classroom, materials are limited to the textbook and supplementary materials which are photocopied. These materials involve cost. For online lessons, a wealth of free, paperless online resources are available.

\begin{tabular}{|c|c|c|}
\hline & Advantages & Disadvantages \\
\hline Online & $\begin{array}{l}\text { EFFICIENCY } \\
\text { - Saves time and cost } \\
\text { MATERIALS } \\
\text { - Wealth of online resources } \\
\text { and audio visual materials } \\
\text { LEARNING EXPERIENCE } \\
\text { - Convenient } \\
\text { - Flexible } \\
\text { - As good as face-to-face } \\
\text { lessons in gaining knowledge } \\
\text { and skills depending on the } \\
\text { students' and teachers. } \\
\text { - Autonomous learning }\end{array}$ & $\begin{array}{l}\text { LEARNER DISCIPLINE } \\
\text {-Difficult to monitor students' } \\
\text { attendance and participation - } \\
\text { Assessment is not reliable } \\
\text { because students are prone to } \\
\text { committing plagiarism. } \\
\text { COMMUNICATION } \\
\text {-Difficulty in getting student } \\
\text { feedback } \\
\text {-Lack of face to face } \\
\text { communication. } \\
\text { - Fewer opportunities for direct } \\
\text { communication. }\end{array}$ \\
\hline
\end{tabular}




\begin{tabular}{|c|c|c|}
\hline & & $\begin{array}{l}\text { LACK OF TECHNICAL } \\
\text { SKILLS/SUPPORT } \\
\text {-Unequipped and unprepared } \\
\text { teachers and students } \\
\text { OPPORTUNITY } \\
\text { INTERACTIVE AND } \\
\text { COLLABORATIVE LEARNING } \\
\text { - Interactive and collaborative } \\
\text { activities that can be } \\
\text { conducted online are limited } \\
\text { due to distance among } \\
\text { learners and teacher. } \\
\text { CATERING TO DIFFERENT } \\
\text { TYPES OF LEARNERS } \\
\text { - Not suitable for weak } \\
\text { students. }\end{array}$ \\
\hline Face to face & $\begin{array}{l}\text { BUILDING PEOPLE SKILLS } \\
\text { - Enables collaborative learning } \\
\text { - communication, teamwork. } \\
\text { CATERING TO DIFFERENT } \\
\text { TYPES OF LEARNERS } \\
\text { - Teaching style can be } \\
\text { modified according to different } \\
\text { learners' needs and learning } \\
\text { styles. }\end{array}$ & $\begin{array}{l}\text { FACILITIES } \\
\text { - Need to depend on facilities. } \\
\text { - Limited facilities available for } \\
\text { audio visual learning such as } \\
\text { language labs, speakers, } \\
\text { EFFICIENCY } \\
\text { - Time consuming } \\
\text { MATERIALS } \\
\text { - Limited learning materials } \\
\text { LEARNER MANAGEMENT } \\
\text { - Classroom management } \\
\text { issues }\end{array}$ \\
\hline
\end{tabular}

Table : Summary of the advantages and disadvantages of online and face to face class

\section{BLENDED LEARNING}

\section{Flexihle}

Effective

\section{Practical}

Although online learning is not suitable for all students, its advantages are that it encourages students to learn independently and exploit various online resources available. It is also much easier to use and access audio visual materials and applications online. Although face to face meeting with students is necessary to provide better guidance, a purely face to face mode is 
also not without limitations. Teachers, students and authorities need to be open in accepting different modes of learning. After all, the success of a lesson depends on various factors other than the mode of learning. It depends on factors such as learners' and teachers' initiatives and characteristics, access to materials, interaction and collaboration opportunities. These are the factors that need to be developed.

Considering the pros and cons of both modes, a blended learning mode would be ideal as it has the benefits of both and one mode complements the weakness of the other (Azizan, 2012.) Further studies can be developed on blended learning. The online mode is not always seen as favourable as it does not provide opportunities for direct communication that is required for a language learning class. It can never replace face-to face-classroom, though it can complement and support it. In having experimented with both modes of learning, it is found that both online and face to face modes have their strengths and weaknesses. It is predicted that blended learning (a combination of both) will be the ideal for all institutions in the future. Once the Covid-19 pandemic comes to an end, it would be a loss to dismiss online mode altogether in favour of a complete face-to-face learning. A number of public and private universities in Malaysia , for example, Open University Malaysia and University of Nottingham are committed to bring the blended learning approach in their teaching and learning activities.

\section{References}

Akyol, Z., \& Garrison, D. R. (Eds.). (2013). Educational communities of inquiry: Theoretical framework, research, and practice. Hershey, PA: IGI Global.

Blake, R. J. (2009). The use of technology for second language distance learning. Modern Language Journal, 93, 822-835.

Bourelle, A., Bourelle, T., Knutson, A. V., \& Spong, S. (2016). Sites of multimodal literacy: Comparing student learning in online and face-to-face environments. Computers and Composition: An International Journal for Teachers of Writing, 39, 55-70. doi:10.1016/j.compcom.2015.11.003

Azizan, F. Z. (2012). Blended learning in higher education institution in Malaysia. Proceedings of Regional Conference on Knowledge Integration in ICT

Garrison, D. R., \& Arbaugh, J. B. (2007). Researching the community of inquiry framework: Review, issues, and future directions. The Internet and Higher Education, 10(3), 157172. doi:10.1016/j.iheduc.2007.04.001

Garrison, D. R., Anderson, T., \& Archer, W. (2000). Critical inquiry in a text-based environment: Computer conferencing in higher education model. The Internet and Higher Education, 2(2-3), 87-105

Heppen, J., Sorensen, N., Allensworth, E., Walters, K., Rickles, J., Taylor, S., \& Michelman, V. (2017). The struggle to pass algebra: Online vs. face-to-face credit recovery for at-risk urban students. Journal of Research on Educational Effectiveness, 10(2), 272-296.

Hocly, N. (2015). Developments in online language learning. ELT Journal, 69(3), 2-6. 2015http://eltj.oxfordjournals.org/

Mehrotra, C., \& McGahey, L. (2012). Online teaching. In B. Schwartz \& R. A. R. Gurung (Eds.), Evidence-based teaching for higher education (pp. 59-76). Washington, DC: American Psychological Association 
Montiel-Chamorro, M. L. (2018). Comparing online English language learning and face-toFace English language learning.(Masters thesis, Virginia Commonwealth University, Virginia, United States). Retrieved from https://scholarscompass.vcu.edu/cgi/viewcontent.cgi?article

$\mathrm{Ni}, \mathrm{A}$. (2013). Comparing the effectiveness of classroom and online learning: Teaching research methods. Journal of Public Affairs Education, 19(2), 199-215.

Palloff, R., \& Pratt, K. (2011). The excellent online instructor: Strategies for professional development. San Francisco, CA: Jossey-Bass

Rienties, B., Giesbers, B., Tempelaar, D., Lygo-Baker, S., Segers, M., \& Gijselaers, W. (2012). The role of scaffolding and motivation in CSCL. Computers and Education, 59(3), 893906

Rubin, B., Fernandes, R., \& Avgerinou, M. D. (2013). The effects of technology on the Community of Inquiry and satisfaction with online courses. The Internet and Higher Education, 17, 48-57

Senior, R. (2010). Connectivity: A framework for understanding effective language teaching in face-to-face and online learning communities. RELC Journal: A Journal of Language Teaching and Research, 41(2), 137-147.

Vygotsky, L. S. (1978). Mind in society: The development of higher psychological processes. Cambridge, MA: Harvard University Press.

Bao, W. (2020). COVID-19 and online teaching in higher education: A case study of Peking University. Human Behaviour and Emerging Technologies, 2(2),113-115 